\title{
Growth inhibitory, apoptotic and anti-inflammatory activities displayed by a novel modified triterpenoid, cyano enone of methyl boswellates
}

\author{
Palaniyandi Ravanan ${ }^{1, \dagger}$, Sanjay K Singh ${ }^{2}$, GSR Subba RaO ${ }^{2}$ and Paturu Kondaiah ${ }^{1, *}$ \\ ${ }^{1}$ Department of Molecular Reproduction, Development and Genetics, ${ }^{2}$ Department of Organic Chemistry, \\ Indian Institute of Science, Bangalore 560 012, India \\ ${ }^{\dagger}$ Present address: Centre for Biomedical Research, School of Biosciences and Technology, \\ Vellore Institute of Technology University, Vellore 632 014, India \\ *Corresponding author (Fax, +91-80-3600999; Email, paturu@mrdg.iisc.ernet.in)
}

\begin{abstract}
Triterpenoids are pentacyclic secondary metabolites present in many terrestrial plants. Natural triterpenoids have been reported to exhibit anti-inflammatory and anti-carcinogenic activities. Here, we show that modifications of ring A of boswellic acid ( 2 cyano, 3 enone) resulted in a highly active growth inhibitory, anti-inflammatory, prodifferentiative and anti-tumour triterpenoid compound called cyano enone of methyl boswellates (CEMB). This compound showed cytotoxic activity on a number of cancer cell lines with $\mathrm{IC}_{50}$ ranging from 0.2 to $0.6 \mu \mathrm{M}$. CEMB inhibits DNA synthesis and induces apoptosis in A549 cell line at $0.25 \mu \mathrm{M}$ and $1 \mu \mathrm{M}$ concentrations, respectively. CEMB induces adipogenic differentiation in 3T3-L1 cells at a concentration of $0.1 \mu \mathrm{M}$. Finally, administration of CEMB intra-tumourally significantly inhibited the growth of C6 glioma tumour xenograft in immuno-compromised mice. Collectively, these results suggest that CEMB is a very potent anti-tumour compound.
\end{abstract}

[Ravanan P, Singh SK, Subba Rao GSR and Kondaiah P 2011 Growth inhibitory, apoptotic and anti-inflammatory activities displayed by a novel modified triterpenoid, cyano enone of methyl boswellates. J. Biosci. 36 297-307] DOI 10.1007/s12038-011-9056-7

\section{Introduction}

The discovery that 2-cyano-3,12-dioxoolean-1,9(11)-diene28-oic acid (CDDO) (Honda et al. 1998), synthesized from naturally abundant oleanolic acid, displayed diverse biological activities ranging from suppression of iNOS and COX2, cellular proliferation of malignant and premalignant cells, to induce differentiation of malignant and nonmalignant cells (Suh et al. 1999), has renewed interest in the pentacyclic triterpenoids and natural products. CDDO and its derivatives are highly active in suppressing cellular proliferation of human leukaemia (Suh et al. 1999; Konopleva et al. 2002; Place et al. 2003; Konopleva et al. 2004), breast cancer (Honda et al. 1999; Lapillonne et al. 2003; Konopleva et al. 2006) and several other cancer cells. In addition, 2-cyano-3,12-dioxooleana-1,9-dien-28-imidazolide (CDDO-Im) exhibits strong inhibitory activity against production of $\mathrm{NO}$, induced by IFN- $\gamma$ in mouse macrophages $\left(\mathrm{IC}_{50}=0.1 \mathrm{nM}\right)$ (Honda et al. 1998; Suh et al. 1999). CDDO was also found to induce monocytic differentiation of human myeloid leukaemia cells and adipogenic differentiation of mouse 3T3-L1 fibroblasts

Keywords. Cancer therapeutics; cytotoxicity; differentiation; natural products

Abbreviations used: AMC, 7-amino-4-methylcoumerin; BrdU, 5-bromo-2'-deoxyuridine; CDDO, 2-cyano-3,12-dioxoolean-1,9-dien28-oic acid; CEMB, cyano enone of methyl boswellates; COX-2, cycloxygenase-2; DAPI, 4',6-diamidino-2-phenylindole; DMEM, Dulbucco's modified eagle's medium; DMSO, dimethyl sulphoxide; DPBS, Dulbucco's phosphate buffer saline; FBS, fetal bovine serum; $\mathrm{IC}_{50}, 50 \%$ inhibitory concentration; IFN IFN- $\gamma$, interferon interferon- $\gamma$; iNOS, induced nitric oxide synthase; MTT, 3-(4,5dimethylthiazolyl-2)-2,5-diphenyltetrazolium bromide); NED, $N$-(1-naphthyl) ethyl-enediamine; TGF- $\beta$, transforming growth factor factor- $\beta$ 
(Suh et al. 1999; Wang et al. 2000). It has been shown that CDDO and CDDO-Im inhibit inflammatory response and tumour growth in vivo (Place et al. 2003). Notably, CDDO-Im is approximately 10 -fold more potent than CDDO in inhibiting cancer cell proliferation and in inducing differentiation in leukaemia cells (Kim et al. 2002). Various derivatives of CDDO also showed potential apoptotic activity on many types of cancer cell lines. For instance, CDDO induces apoptosis of acute myelogenous leukaemia (Konopleva et al. 2004), osteosarcoma (Ito et al. 2001) and skin cancer (Hail et al. 2004). The methyl ester of CDDO, CDDO-Me, triggers apoptosis in lung carcinoma (Kim et al. 2002) and prostate cancer cells (Hyer et al. 2008) whereas its imidazole ester, CDDO-Im, induces apoptosis in pancreatic (Samudio et al. 2005) and ovarian cancer (Petronelli et al. 2009). Despite the multifunctional activities of synthetic triterpenoids, the molecular mechanisms that mediate the effects are not fully understood except that CDDO and its derivatives have been shown to induce apoptosis either by activating intrinsic mitochondria-dependent or extrinsicdeath-receptor-mediated pathways, depending on the cell types (Ito et al. 2000, 2001; Samudio et al. 2006; Brookes et al. 2007). In addition, it has recently been shown that CDDO-Me activates endoplasmic reticulum stress (ER stress) and thereby triggers the DR5-mediated apoptotic pathway (Zou et al. 2008). CDDO and derivative compounds are being used in phase I/II clinical trials as novel cancer therapeutic agents (Liby et al. 2007b; Hyer et al. 2008). All these studies suggest the potential of modified triterpenoids in anti-inflammatory and anti-carcinogenic applications.

Although, CDDO and its derivatives show great promise as therapeutic molecules, it is important to explore other triterpenoids for their efficacy in these actions, to provide alternatives to CDDO. A recent publication suggests that modified betulinic acid also shows activities similar to those reported for CDDO (Liby et al. 2007a). However, it is necessary to explore other triterpenoids because of uncertainties in their metabolic turnover and other potential side effects that may be dependent on the molecular species. To this end, we obtained several triterpenoids available from Indian plants and made chemical modifications that are similar to CDDO. The details of their synthesis, characterization and preliminary activities of these triterpenoids such as inhibition of IFN- $\gamma$-induced NO production and cytotoxicity have been reported earlier (Subba Rao et al. 2008).

Here we report that cyano-enone modified methyl boswallates (CEMB) (figure 1) (1) is a potent inhibitor of NO production induced by IFN- $\gamma$ in elicited mouse primary macrophages, (2) is an inhibitor of DNA synthesis, (3) is an inducer of caspase 8 and caspase 3 activation and thereby apoptosis in A549 cells, (4) is an inducer of adipogenic differentiation in 3T3-L1 cells and (5) has anti-tumour activity on tumour xenografts in mouse model. Our results suggest the potential of CEMB as a chemotherapeutic agent.

\section{Materials and methods}

\subsection{Cell cultures and reagents}

Dimethyl sulphoxide (DMSO), 3-(4,5-dimethylthiazolyl-2)2,5-diphenyltetrazolium bromide (MTT), phosphoric acid, $N$-(1-naphthyl) ethyl-enediamine (NED) and sulfanilamide were purchased from Sigma. Dulbucco's modified eagle's medium (DMEM), DMEM-F12, RPMI, Dulbucco's phosphate buffer saline (DPBS), certified fetal bovine Serum, penicillin-streptomycin, amphotericin $\mathrm{B}$ and trypsin were purchased from GIBCO. Caspase 8 and Caspase 3 Activity Assay Kits were from Sigma (Product code: CASP-8-F and CASP-3-F). 5-Bromo-2'-deoxyuridine (BrdU), anti-BrdU

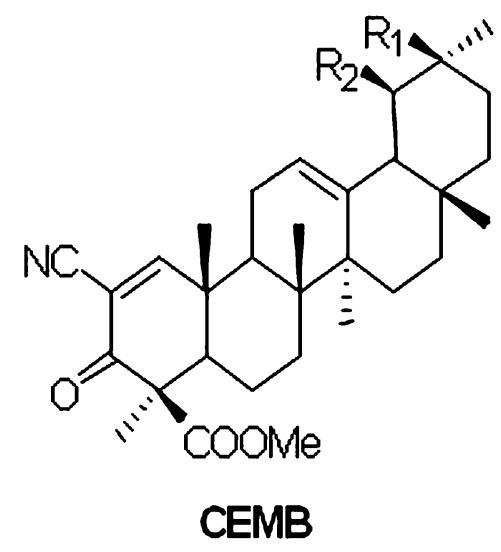

$R_{1}=H, R_{2}=M e ;$ from $\beta$ boswellic adid $R_{2}=H_{1} R_{1}=$ Me; from $\alpha$-boswellic adid

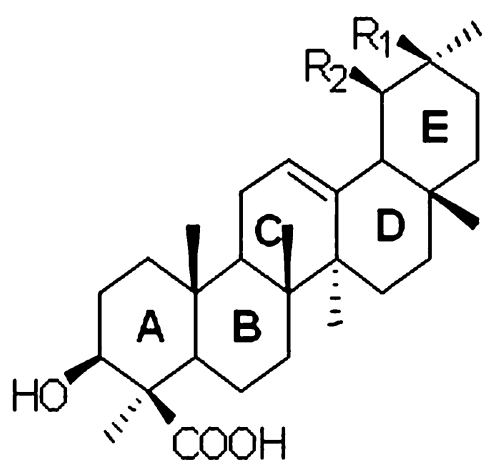

Boswellic acids

$R_{1}=H_{1} R_{2}=$ Me; $\beta$-boswellic acid

$R_{2}=H_{1} R_{1}=M e ; \alpha$ boswellic acid

Figure 1. Structure of CEMB. The structure of synthetic triterpenoids CEMB and the parent compound of CEMB, boswellic acid. 
antibody (ab-3) and Texas red-conjugated goat antimouse antibody were purchased from Oncogene. Human cancer cell lines A549, A431, HT1080, HepG2, HeLa, HCT116, MCF-7, T47D, T84, CaCO2, JEG, PC3, mouse 3T3-L1, Rat C6 glioma cells, and human keratinocyte cell line HaCaT were routinely grown in DMEM with $10 \%$ FBS. Jurkat, HL60, THP-1 and K562 cell lines were grown in RPMI with $10 \%$ FBS. Penicillin-streptomycin and amphotericin B were added in the culture to prevent microbial growth. CEMB was synthesized from boswellic acid as described previously. CEMB was dissolved in DMSO at $10 \mathrm{mM}$ concentration and stored at $-20^{\circ} \mathrm{C}$. The dilutions were made in culture medium just before the treatments.

\subsection{Nitric oxide assay}

Two-month-old C57black6 mice were injected intraperitoneally with $4 \%$ thioglycolate route. On the third day, the mice were sacrificed by cervical dislocation, and $6 \mathrm{ml}$ of $0.32 \mathrm{M}$ sucrose solution was injected in to the peritoneal region, and the macrophages were collected. Cells were centrifuged, washed with DPBS and plated $\left(1.5 \times 10^{5}\right.$ cells/ well) in a 96-well plate. The cells were treated with IFN- $\gamma$ $(10 \mathrm{U} / \mathrm{ml})$ in the presence or absence of CEMB and incubated for 3 days. NO was rapidly oxidized to nitrite in the culture medium (RPMI+10\% FBS), and determination of nitrite concentration was used as a measure of NO production. Equal volumes of cell supernatants and Griess reagent (Ding et al. 1990) were added to individual wells of a 96-well plate and the absorbance was measured at $590 \mathrm{~nm}$ in an ELISA reader. Nitrite concentration was estimated using a sodium nitrite standard curve. Nitrite concentration was normalized with total protein determined by the Bradford method. The experiments were performed multiple times and the result presented here are from three independent experiments. Graph Pad Prism software was used to assess the inhibitory concentration $\left(\mathrm{IC}_{50}\right)$ of the compound.

\subsection{Cytotoxicity assay using MTT reagent}

The cells were plated in 96-well tissue culture clusters (seeded at densities ranging from $5 \times 10^{3}$ to $8 \times 10^{3}$ cells/well) depending on the cell line and incubated at $37^{\circ} \mathrm{C}$ in $5 \% \mathrm{CO}_{2}$ atmosphere. After attachment of the cells (usually taking 3$4 \mathrm{~h}$ ), different concentrations of the compound were added and incubated for $72 \mathrm{~h}$. MTT solution ( $20 \mu \mathrm{lof} 5 \mathrm{mg} / \mathrm{ml}$ ) was added to each well and the incubation continued for an additional $3 \mathrm{~h}$. The dark blue formazan crystals formed within the healthy cells were solubilized with DMSO, the plates read in ELISA plate reader (7520 Microplate Reader, Cambridge Technologies Inc.) at $550 \mathrm{~nm}$ and the absorbance was correlated with the cell number. Experiments were performed in triplicates and the values are the average of three $(n=3)$ independent experiments. The inhibitory concentration $\left(\mathrm{IC}_{50}\right)$ of the compound was assessed by Graph Pad Prism software.

\subsection{Cell proliferation assay using BrdU incorporation}

BrdU incorporation assay was carried out as described earlier (Wajapeyee and Somasundaram 2003). In brief, cells were plated at a density of $1.2 \times 10^{4}$ cells/well in a 96-well plate. After $24 \mathrm{~h}$, cells were treated with the compound for another $24 \mathrm{~h}$ and $\mathrm{BrdU}(20 \mu \mathrm{M})$ was added to the culture medium $4 \mathrm{~h}$ prior to the termination. The cells were washed with phosphate buffered saline (DPBS) and fixed with 70\% ethanol for $5 \mathrm{~min}$. The cells were washed again with DPBS and incubated with $2 \mathrm{~N} \mathrm{HCl}+$ Triton $\times 100$ to denature the chromosomal DNA. The cells were washed thrice to completely remove $\mathrm{HCl}$, followed by incubation again with $1 \%$ BSA for blocking nonspecific binding. BrdU incorporation was determined by treating with anti-BrdU antibody and Texas red conjugated goat-antimouse IgG.

\subsection{DNA fragmentation assay}

Low-molecular-weight genomic DNA was extracted as described previously (Yawata et al. 1998). In brief, approximately $1 \times 10^{6}$ cells were plated and treated with $1 \mu \mathrm{M}$ (A549 cells) and $0.5 \mu \mathrm{M}$ (HL60 cells) of CEMB for various treatment hours. All the cells (including floating cells) were harvested by trypsinization and washed with DPBS. Cells were lysed with the lysis buffer, andtreated $40 \mathrm{mg} / \mathrm{ml}$ RNase $\mathrm{A}$ and proteinase $\mathrm{K}$ at $37^{\circ} \mathrm{C}$ for $1 \mathrm{~h}$. DNA was precipitated using isopropanol, and subjected on to $1.0 \%$ agarose gels. The gels were stained with $1 \mu \mathrm{g} / \mathrm{ml}$ ethidium bromide.

\subsection{Caspase activity assay}

Caspase assays were performed using fluorometric kits (Sigma-Aldrich, St. Louis, USA). The cells were treated with CEMB $(1 \mu \mathrm{M})$ for 3, 6, 12 and $24 \mathrm{~h}$ and lysed with the lysis buffer ( $50 \mathrm{mM}$ HEPES, pH 7.4, with $5 \mathrm{mM}$ CHAPS and $5 \mathrm{mM}$ DTT). Later, $100 \mu \mathrm{l}$ of the lysate was incubated with the caspase 3 or caspase 8 peptide substrates (AcDEVD-AMC and Ac-IETD-AMC, respectively) for $1 \mathrm{~h}$ as described in the manufacturer's protocol (Caspase 8 and Caspase 3 Assay Kits, Fluorometric,SIGMA). Caspase inhibitors were also used to confirm the result. The caspase activity was represented as quantity of fluorescent 7-amino4-methylcoumerin (AMC) released/mg protein $/ \mathrm{h}$.

\subsection{Oil red $O$ staining}

Induction of differentiation in 3T3-L1 cells was performed as described earlier (Wang et al. 2000). In brief, 3T3-L1 
fibroblasts cells were seeded in 6-well plate at a cell density of 0.4 million cells/well and cultured for around 4 days until it reached confluence. The culture medium was replaced with fresh medium once in 2 days. Cells were treated with CEMB at various concentrations starting from $0.05 \mu \mathrm{M}$ to $0.25 \mu \mathrm{M}$. The standard method to induce adipogenesis (0.5 mM IBMX $+0.5 \mu \mathrm{M}$ dexamethasone $+1.7 \mu \mathrm{M}$ insulin) was also included in the experiment to compare the efficiency of CEMB-induced differentiation. To stain the triglycerides, cells were washed twice with PBS and fixed in $3.7 \%$ formaldehyde for $1 \mathrm{~h}$ followed by oil red $\mathrm{O}$ staining as described previously (Hansen et al. 1999).

\subsection{Tumour xenograft study}

Female nude mice at approximately 2 months age and 20-25 g weight were used for tumour xenograft studies. C6 rat glioma cells were injected subcutaneously $\left(3 \times 10^{6}\right.$ cells $/$ mouse $)$ over the left flank of mice (day 0). After 4 days, treatment with CEMB was initiated with CEMB in DMSO, castor oil and PBS mixed in the ratio of 1:1:8 in $0.1 \mathrm{ml}$ solution and injected at the site of the tumours. An equivalent number of mice were injected with vehicle control (DMSO, castor oil and PBS in the same proportions). The treatment was carried out twice daily (every $12 \mathrm{~h}$ ) for the first 2 days and then daily (every $24 \mathrm{~h}$ ) for 3 more days. On day 14, the mice were sacrificed and tumours was excised and weighed. A portion of the tumour was fixed in $10 \%$ buffered formalin for histological analysis.

\section{Results}

\subsection{CEMB inhibits NO production in primary mouse macrophages}

To test whether CEMB inhibits NO production, mouse primary macrophages were plated and $\mathrm{NO}$ production was induced by IFN- $\gamma$, in the presence or absence of CEMB. Natural boswellic acid has been reported to possess antiinflammatory activity at a concentration of $40 \mu \mathrm{M}$ (Gayathri et al. 2007). In our study, $20 \mu \mathrm{M}$ of boswellic acid was used as the highest concentration, and at this concentration, naturally occurring boswellic acid did not inhibit NO production (data not shown). However, appropriate modifications in the $\mathrm{A}$ ring resulted in CEMB showed potent inhibition of $\mathrm{NO}$ production $\left(\mathrm{IC}_{50}=57.3 \mathrm{nM}\right)$ in a concentration-dependent manner starting from 1, 0.1, 0.01 and $0.001 \mu \mathrm{M}$ (figure 2). DMSO was used as a negative control, whereas CDDO and CDDO-Me were used as positive controls. We observed that $\mathrm{CDDO}$ and CDDO-Me were more potent in inhibiting $\mathrm{NO}$ production $\left(\mathrm{IC}_{50} \leq 1 \mathrm{nM}\right)$ than CEMB.

\subsection{Cytotoxic effect of CEMB in tumour cell lines}

To investigate whether CEMB inhibits cancer cells growth, various tumour cell lines were treated with different concentrations of CEMB and evaluated using MTT assay. The CEMB treatment resulted in reduced concentration of formazan crystals, indicating either a growth inhibitory or cytotoxic effect of CEMB. The compound was active in all cancer cell lines we tested with $\mathrm{IC}_{50}$ ranging from $0.10 \mu \mathrm{M}$ (HL60) to $0.7 \mu \mathrm{M}$ (MCF7) (table 1). Lung and breast carcinoma cells $\left(\mathrm{IC}_{50} \geq 0.7 \mu \mathrm{M}\right)$ were comparatively less sensitive to the compound than the leukaemia cells $\left(\mathrm{IC}_{50} \leq 0.25 \mu \mathrm{M}\right)$. The percentage of cells showing cytotoxicity at $1 \mu \mathrm{M}$ concentration was in the range of $97 \%$ (Raji cells-Bcl-2 overexpressed) to $56.8 \%$ (JEG cells). These results indicate that the compound CEMB has a potent cytotoxic/growth inhibitory activity.

\subsection{CEMB inhibits DNA synthesis preferentially in carcinoma cells}

By MTT assay, CEMB was found to be a potent cytotoxic/growth inhibitory molecule. In order to test whether CEMB is specific against cancer cells, A549 (human lung carcinoma) and $\mathrm{HaCaT}$ (human keratinocyte) cells were treated with CEMB at various concentrations. BrdU incorporation assay was done as described in materials and methods. As shown in figure 3, CEMB inhibited BrdU incorporation in both the cell lines at higher concentrations. However, at lower concentration, we observed differential sensitivity between $\mathrm{A} 549$ and $\mathrm{HaCaT}$ cells (compared at $0.1 \mu \mathrm{M}$ and $0.25 \mu \mathrm{M})$. This differential response could be due to cell type differences. Alternatively, this could be due to higher sensitivity of tumour cells to CEMB than the normal cells. An extensive validation of this study in various cell lines of tumour and normal origin is required to confirm the finding.

\subsection{CEMB induces DNA fragmentation}

CEMB showed cytotoxic activity on various cancer cell lines and it also affects DNA synthesis, at least in A549 cells. In order to delineate the mechanism of cell death mediated by CEMB, we performed DNA fragmentation assay, which is characteristic for apoptosis. A549 (24, 48, and $72 \mathrm{~h}$ treatments) and HL60 (12, 24 and $48 \mathrm{~h}$ treatments) cells were treated with $1 \mu \mathrm{M}$ and $0.5 \mu \mathrm{M}$ of CEMB, respectively. Low-molecular-weight DNA from these cells was resolved in $1.0 \%$ agarose gels. Figure 4A shows DNA ladder formation in A549 cells at indicated time points at a concentration of $1 \mu \mathrm{M}$. Figure $4 \mathrm{~B}$ shows DNA ladder formation after $48 \mathrm{~h}$ of treatment in HL60 cells at $0.5 \mu \mathrm{M}$ concentration. These data suggest that CEMB is a potent inducer of apoptosis in A549 and HL60 cells. 


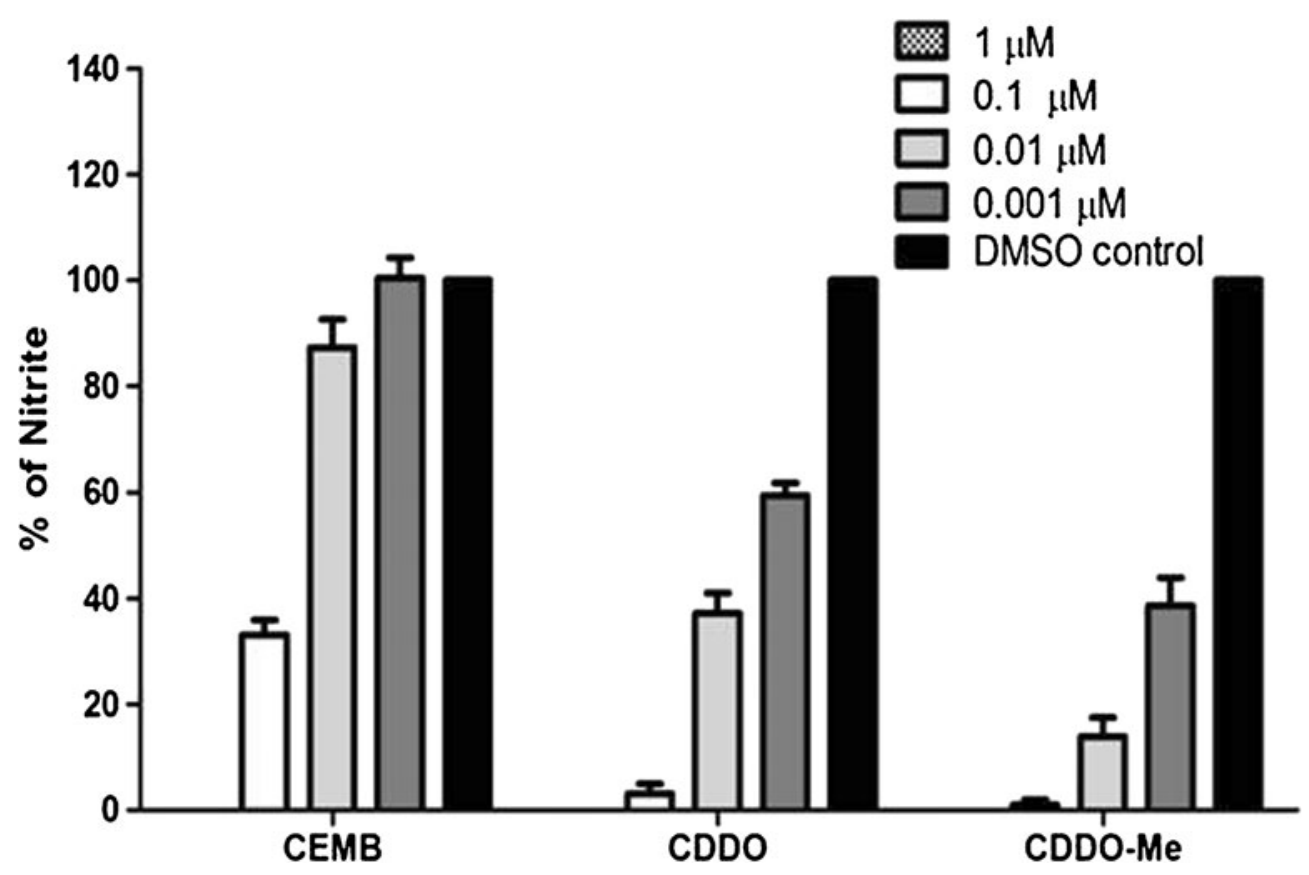

Figure 2. Nitric oxide assay on mouse primary macrophages using Griess reagent. Mice were injected with $4 \%$ thioglycolate solution and sacrificed on the third day. Macrophages were collected with $0.32 \mathrm{M}$ of ice cold sucrose solution. The collected cells were plated at a density of $1.5 \times 10^{5}$ cells/well in a 96-well plate. After 3-4 h, the cells were treated with IFN- $\gamma(10 \mathrm{U} / \mathrm{ml})$ in presence or absence of CEMB with various concentrations for $72 \mathrm{~h}$. Griess assay was done as described in materials and methods. The experiment was performed at least three times and the result presented here is the mean \pm SEM of three independent experiments.

Table 1. Cytotoxic effect of CEMB on cancer cell lines

\begin{tabular}{|c|c|c|c|c|}
\hline No. & Cell line & Description & $\%$ of cytotoxicity at $1 \mu \mathrm{M}$ conc. & $1 \mathrm{C}_{50}(\mu \mathrm{M})$ \\
\hline 1 & A549 & Lung carcinoma & $77.4 \pm 11$ & 0.51 \\
\hline 2 & PC3 & Prostate carcinoma & $71.7 \pm 7$ & 0.51 \\
\hline 3 & K562 & Leukemia & $58.6 \pm 7$ & 0.24 \\
\hline 4 & Jurkat & Leukemia & $83.7 \pm 1$ & 0.16 \\
\hline 5 & THP-1 & Leukemia & $72.5 \pm 6$ & 0.25 \\
\hline 6 & $\mathrm{HeLa}$ & Cervical carcinoma & $78.5 \pm 3$ & 0.27 \\
\hline 7 & $\mathrm{CaCo} 2$ & Colon carcinoma & $71.5 \pm 9$ & 0.35 \\
\hline 8 & T84 & Colon carcinoma & $65.5 \pm 0.5$ & 0.29 \\
\hline 9 & MCF-7 & Breast carcinoma & $61.4 \pm 11$ & 0.70 \\
\hline 10 & HepG2 & Hepato carcinoma & $86.6+3$ & 039 \\
\hline 11 & T47D & Breast carcinoma & $79.1 \pm 5$ & 0.55 \\
\hline 12 & JEG & Chorio carcinoma & $56.8 \pm 16$ & 0.23 \\
\hline 13 & HCT116 & Colon carcinoma & $68.4 \pm 1$ & 0.31 \\
\hline 14 & HT1080 & Fibrosarcoma & $60.8 \pm 5$ & 0.34 \\
\hline 15 & C6 & Rat glioma & $82.8 \pm 1$ & 0.34 \\
\hline 16 & Jurkat (C8 deficient) & Leukemia & $79.1 \pm 5$ & 0.24 \\
\hline 17 & Raji (Bcl-2 over expressed) & Lymphoma & $96.4 \pm 0.4$ & 0.12 \\
\hline 18 & HL60 & Leukemia & $95.0 \pm 0.6$ & 0.10 \\
\hline
\end{tabular}

Cells were plated $\left(5 \times 10^{3}-8 \times 10^{3}\right)$ cells/well in a 96 -well cluster plate. After $3-4 \mathrm{~h}$, the cells were treated with various concentrations of CEMB. MTT assay was done after $72 \mathrm{~h}$ of incubation. The results are presented as the mean \pm SEM of three independent experiments. $\mathrm{IC}_{50}$ values were calculated using Graph Pad Prism software. 


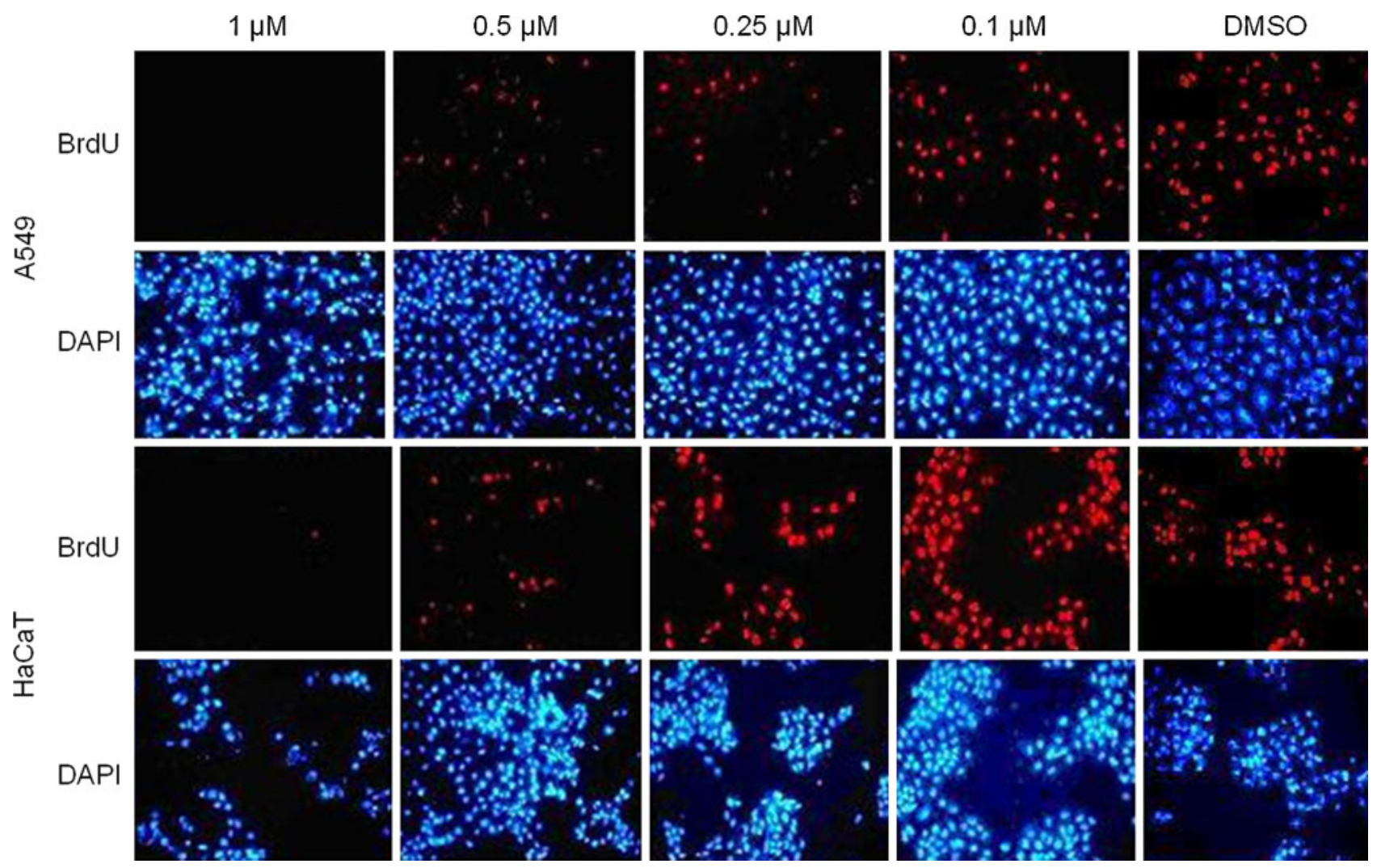

Figure 3. BrdU incorporation assay. A549 and HaCaT cells were plated in a 96-well plate and treated with CEMB for $24 \mathrm{~h}$. BrdU $(20 \mu \mathrm{M})$ was added after $20 \mathrm{~h}$ of treatment for a period of $4 \mathrm{~h}$. BrdU staining was done using anti-BrdU antibody as described in materials and methods. The experiment was performed twice.

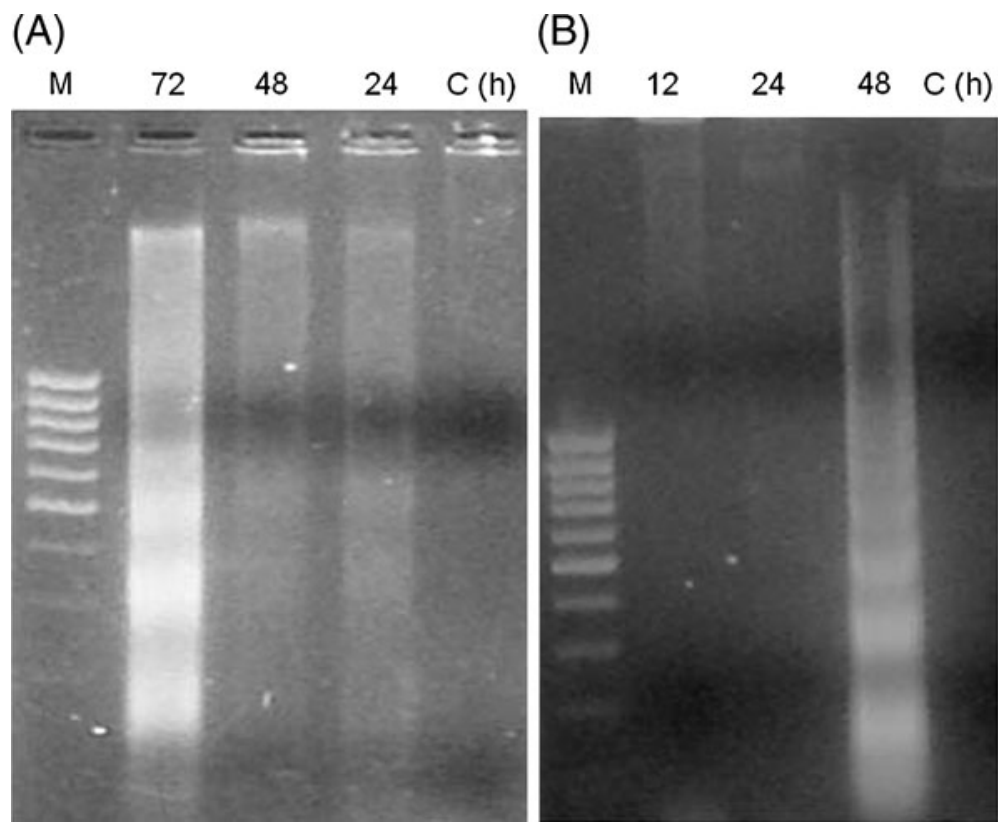

Figure 4. DNA fragmentation of A549 (A) and HL60 (B) exposed to CEMB. (A) A549 cells were treated with CEMB at $1 \mu \mathrm{M}$ concentration for 24, 48 and $72 \mathrm{~h}$. (B) HL60 cells were incubated with $0.5 \mu \mathrm{M}$ of CEMB for 12, 24 and $48 \mathrm{~h}$. DNA laddering formation was viewed on ethidium bromide-stained gel. M, molecular weight marker; C, DMSO control. 


\subsection{CEMB activates caspase 8 and caspase 3}

Because CEMB induces cell death by apoptosis, we tested to check whether caspase 3 and caspase 8 were involved in the apoptotic process. A549 cells were treated with $1 \mu \mathrm{M}$ of CEMB for various durations $(3,6$, 12 and $24 \mathrm{~h}$ ). As shown in figure 5, both caspase 8 (figure 5A) and caspase 3 (figure 5B) enzymes are

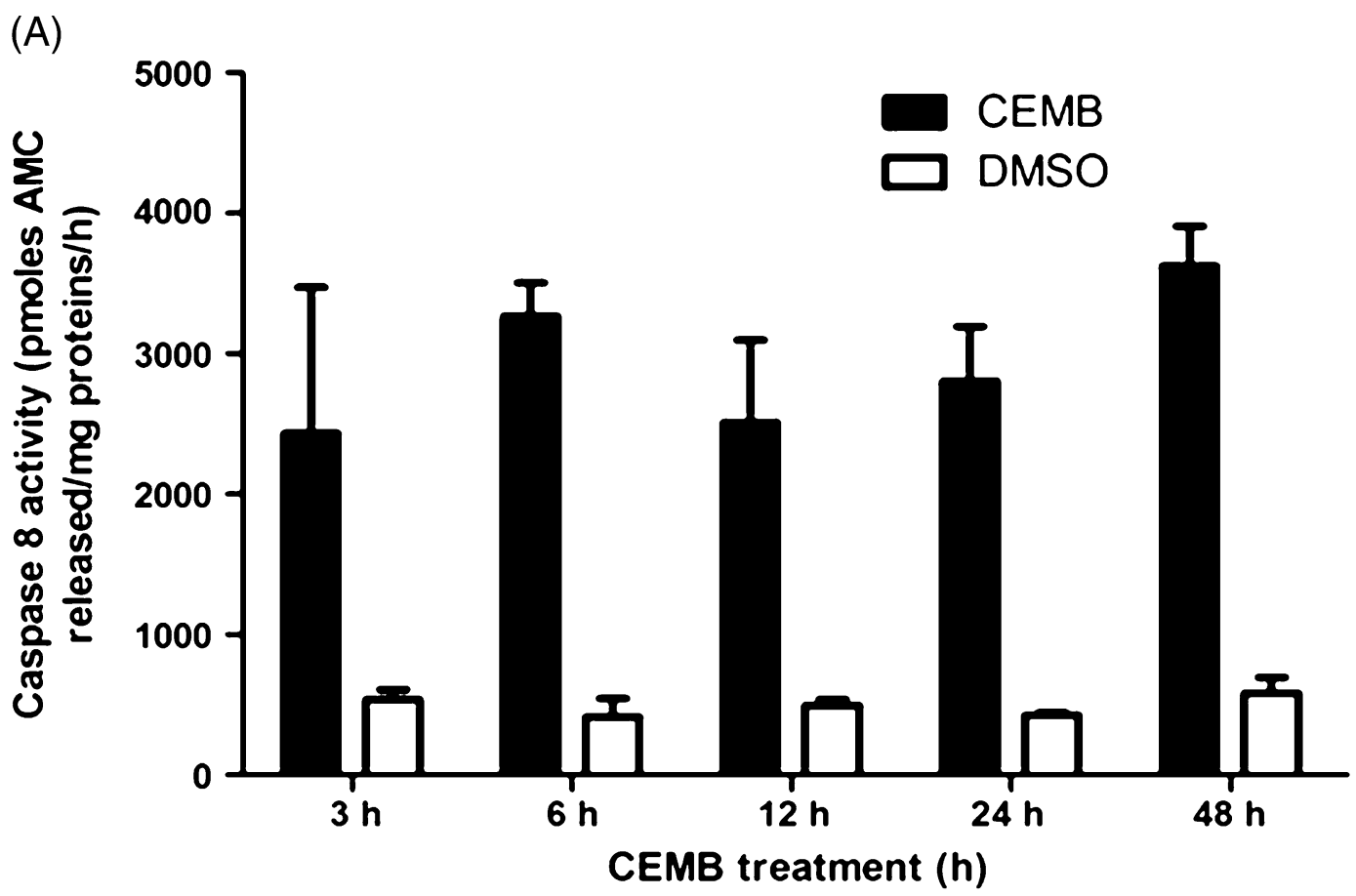

(B)

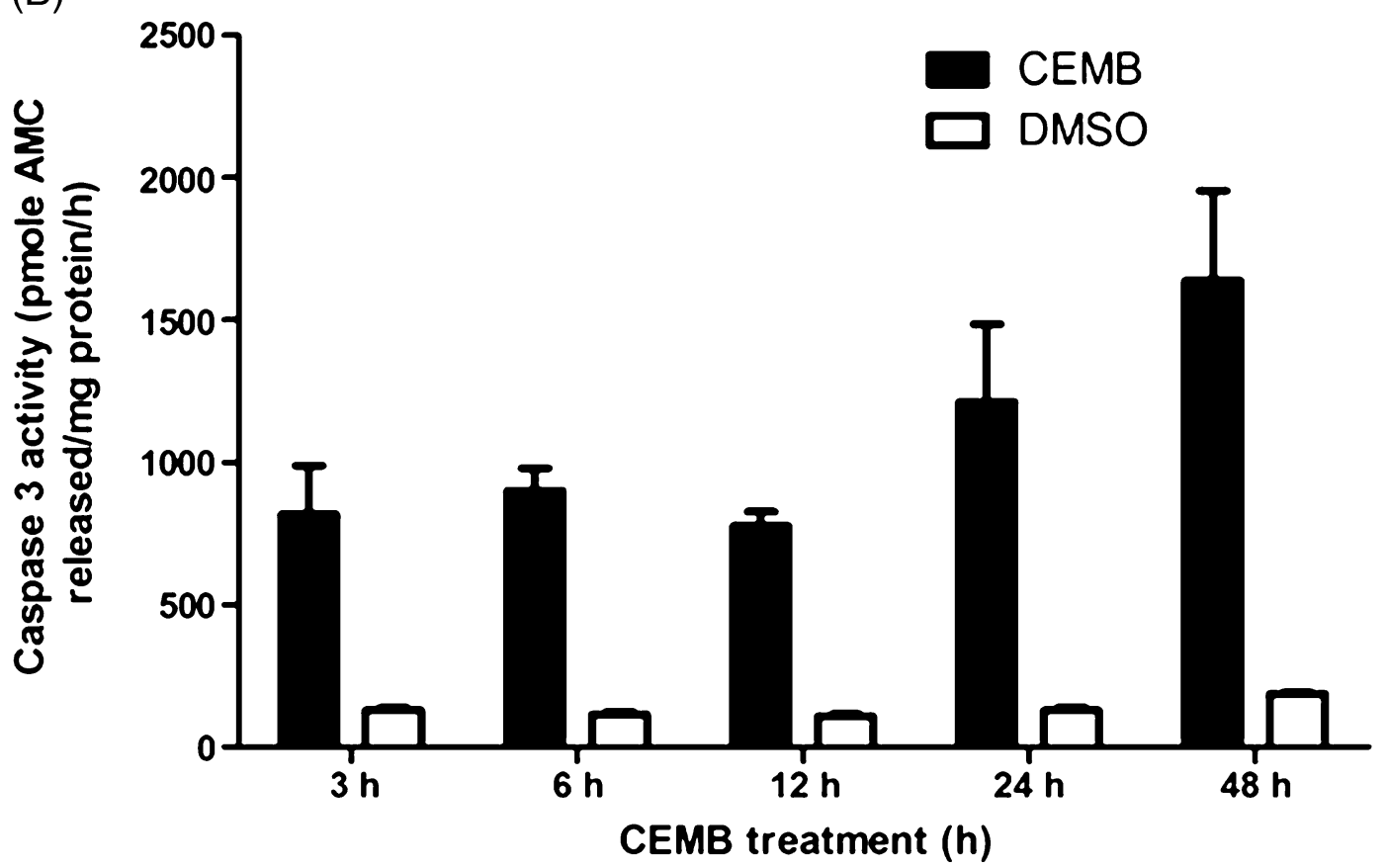

Figure 5. Activation of caspase 8 (A) and caspase 3 (B) exposed to CEMB. A549 cells were treated with CEMB (1 $\mu$ M) for increasing time points. Caspase activity assay was carried out using appropriate fluorogenic-caspase substrates, measured in a fluorimeter. The results presented are the mean \pm SEM of two independent experiments. 
activated in A549 cells at all time points we tested, starting as early as $3 \mathrm{~h}$. A maximal activity of 8.5- and 6.2-fold for caspase 8 and 3, respectively, was observed after $48 \mathrm{~h}$ of treatment. DMSO was used as a negative control for each time points. This establishes CEMB as a potent inducer of apoptosis by activating of caspase 8 and caspase 3 in A549 cells.

\subsection{Induction of differentiation in 3T3-L1 cells by CEMB}

Natural triterpenoids and synthetic triterpenoids have been shown to induce differentiation in malignant and nonmalignant cells. To determine whether CEMB is capable of inducing differentiation, we tested CEMB on 3T3-L1 fibroblast cell line, which is known to induce adipogenesis. To test this, cells were plated and allowed to reach confluence. After $48 \mathrm{~h}$, cells were treated with $50 \mathrm{nM}$ and $100 \mathrm{nM}$ of CEMB for $48 \mathrm{~h}$ as described in materials and methods and stained with oil red O dye. DMSO was used as a negative control. 3-Isobutyl-1-methylxanthine (IBMX) was used as a positive control for differentiation of 3T3L1 cells. As shown in figure 6, treatment of 3T3-L1 cells with CEMB-induced adipogenic differentiation is seen by the increased number of oil droplets (stained with oil red $\mathrm{O}$ ) in both $50 \mathrm{nM}$ and $100 \mathrm{nM}$ treatments.

\subsection{CEMB suppresses tumour growth in xenografts mouse model}

Our in vitro studies showed that CEMB is a potent apoptotic agent for most tumour cell lines. To study the activity of CEMB in vivo, subcutaneous C6 rat glioma tumours were induced in nude mice as described in the methods section. CEMB treated tumours showed a reduction in both size (volume) and weight (figure 7A). In the group of mice treated with $100 \mu \mathrm{g} /$ day $\mathrm{CEMB}$, the tumour weight was $0.23 \pm 0.09 \mathrm{~g}$, whereas treatment with $200 \mu \mathrm{g}$ /day showed tumour weights of $0.1 \pm 0.03 \mathrm{~g}$ (figure 7B), compared with $0.38 \pm 0.10 \mathrm{~g}$ with vehicle control. Histological analysis of tumours showed that CEMB-induced cell death was apoptotic and necrotic in the tumour tissue. Thus, CEMB displays in vivo anti-tumour activity against C6 glioma, at least under these experimental conditions.

\section{Discussion}

The results presented here, reveal that modification to the $\mathrm{A}$ ring of pentacylcic triterpenoid $\alpha$ and $\beta$ boswellic acids (extracted from Boswellia serrata) potentiates the antiinflammatory and anti-carcinogenic properties of the compound. As the separation of the $\beta$ and $\alpha$ (60:40) isomers of boswellic acid is a tedious process, we performed the synthetic scheme on the mixture to generate the CEMB (Subba Rao et al. 2008). In our study, we screened the compound CEMB on a number of cancer cell lines from different tissue origins. We found that CEMB is a potent cytotoxic agent $\left(\mathrm{IC}_{50} \sim 0.15-0.7 \mu \mathrm{M}\right)$ by the MTT assay on several cell lines. We have also shown that CEMB inhibits DNA synthesis in lung carcinoma cell line A549 and this effect is comparatively less in an untransformed cell line such as $\mathrm{HaCaT}$, particularly at 0.25 and $0.1 \mu \mathrm{M}$ concentrations. This compound is also shown to possess anti-inflammatory property as it inhibits $\mathrm{NO}$ production $\left(\mathrm{IC}_{50} \sim 0.05 \mu \mathrm{M}\right)$ induced by IFN- $\gamma$. A strong link between cancer and inflammation is well known in lung, colon, bladder, cervical, pancreas and stomach cancers (Aggarwal et al. 2006; Lu et al. 2006). NO is a multifactorial molecule in tumourogenesis, known to participate in carcinogenesis by inducing DNA damage, supporting tumour progression and suppression of immune response (Lala and Orucevic 1998). NO also plays an important role in angiogenesis, invasion and metastatic processes (Palmer et al. 1988; Radomski et al. 1990). Therefore, inhibiting NO production could facilitate cancer therapy. 3T3-L1 mouse fibroblasts cells show induction of adipogenic differentiation in the presence of differentiation inducers (IBMX, dexamethasone and insulin). In our study, using CEMB we have shown that in absence of these inducers, CEMB $(0.05-0.1 \mu \mathrm{M})$ alone could induce differentiation.

In the present work, we have shown that CEMB induces cell death via apoptosis. Specifically, we have demonstrated that CEMB activates the death-receptor-mediated caspase

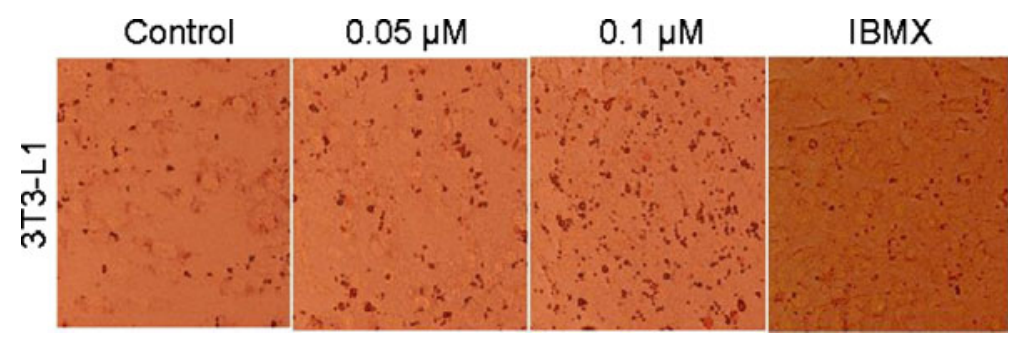

Figure 6. CEMB induces differentiation. 3T3-L1 cells were treated with CEMB and the intracellular triglycerides accumulation was stained using Oil Red O. IBMX, standard method to induce differentiation; control, neither with differentiation cocktail nor CEMB. 
(A)

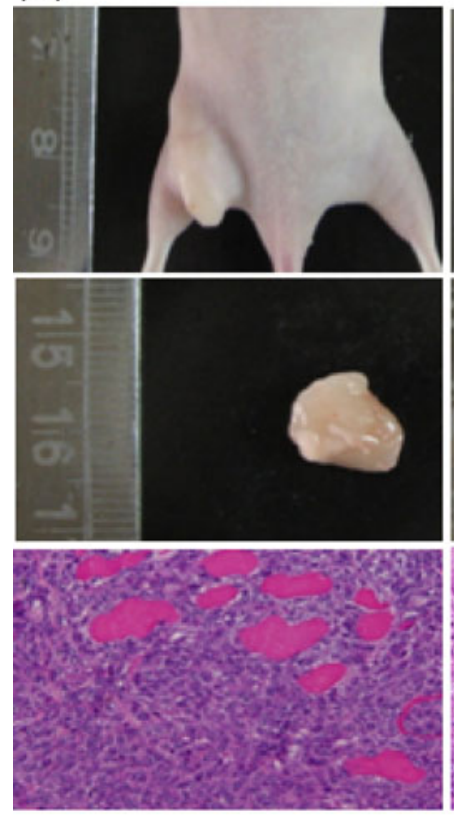

Control
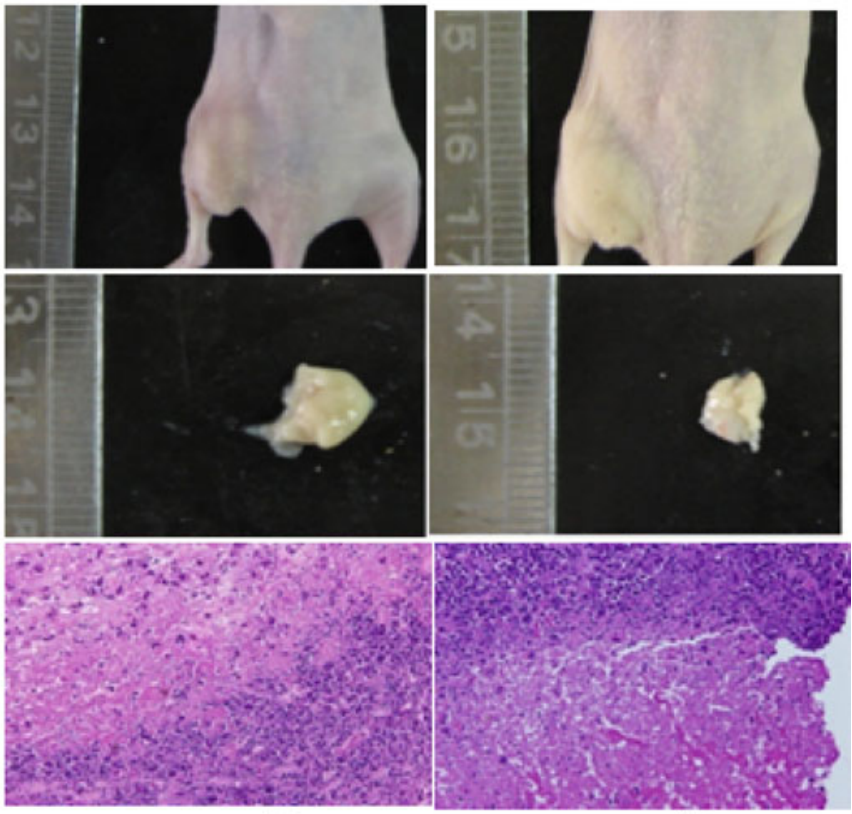

$100 \mu \mathrm{g} / \mathrm{day}$

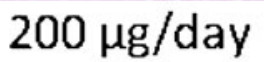

(B)

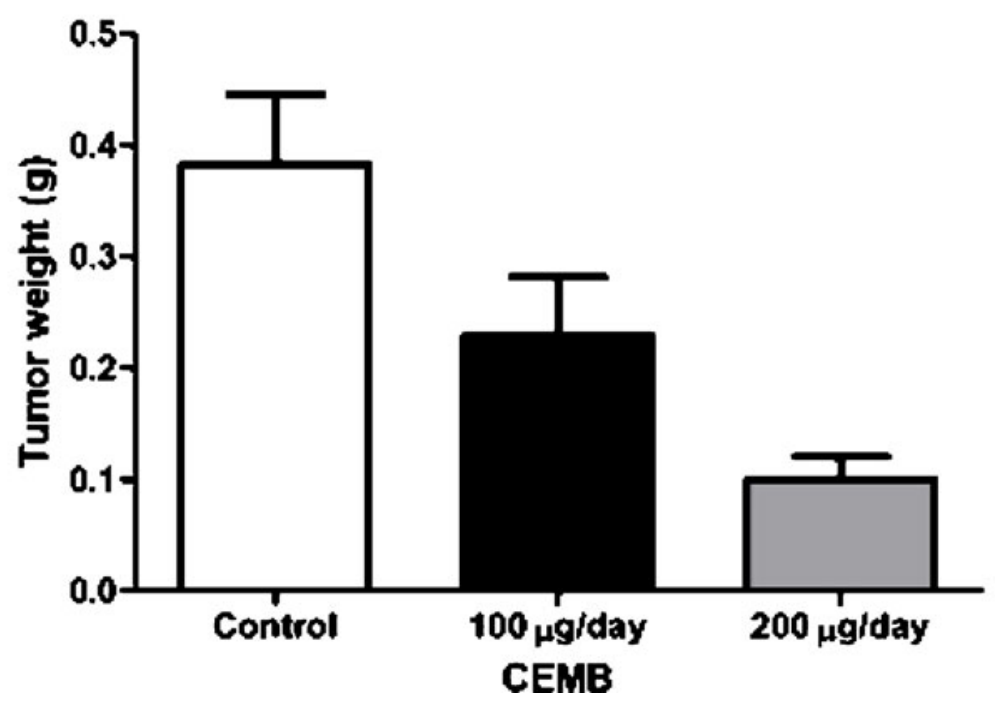

Figure 7. In vivo effect of CEMB on xenograft mouse model. (A) Nude mice were subcutaneously injected with $\mathrm{C} 6$ rat glioma $\left(3 \times 10^{6}\right)$ cells /mouse over the left flank of mice (day 0). After 4 days, CEMB in DMSO, castor oil and PBS was mixed in the ratio of 1:1:8 in $0.1 \mathrm{ml}$ solution and injected at the site of tumours. Equal number of nude mice were injected with DMSO, castor oil and PBS (1:1:8) as vehicle control. The treatment was carried out twice a day (every $12 \mathrm{~h}$ ) for the first 2 days and then daily (every 24 h) for 3 more days. On day 14, the mice were sacrificed and tumours were excised and weighed. (B) Tumour weights of each group computed as mean of three tumours weights from three different nude mice \pm SEM.

8 apoptotic pathway, leading to caspase 3 activation followed by DNA breakage. We have tested CEMB on caspase 8 deficient Jurkat cells and Bcl-2-overexpressed Raji cells. In MTT assay, CEMB was surprisingly sensitive even to the Jurkat cells that are caspase 8 deficient, indicating that CEMB can also trigger caspases-independent cell death mechanisms. Bcl-2 has been extensively studied for chemoresistance as it is able to suppress chemotherapy-induced apoptosis (Korsmeyer 1992; Yang and Korsmeyer 1996; Reed 1997). Interestingly, we observed that CEMB was effective even in Bcl-2-overexpressed cells, suggesting that CEMB is capable of inducing cell death in cells resistant to 
apoptosis. The actual mechanism of cell death in caspase-8deficient and Bcl-2-overexpressed cells remains to be established. This is an important observation and extensive testing is warranted to confirm the effectiveness of this compound on drug-resistant tumour cells. Furthermore, we have tested the in vivo effect of CEMB on a xenograft tumour model in immuno-compromised mice. Our data show that CEMB significantly reduced the tumour size in a dosedependent manner, suggesting the potential of this as an anticancer compound.

In summary, we conclude that CEMB is a novel synthetic triterpenoid compound showing potent cytotoxic, growth inhibitory, anti-inflammatory and pro-differentiative activities. CEMB induced cell death is via apoptosis in A549 cells, mediated by caspase 8. CEMB could effectively reduce the tumour size in xenograft mouse model. Thus we advocate further studies to explore the development of CEMB as an anti-tumour therapeutic agent.

\section{Acknowledgements}

We thank Dr Vani Santosh for her help with the histology of tumours. This project was funded by a grant support received from National Institute of Health (NIH)/FIRCA, USA. Infrastructure support received from DST-FIST, UGC-SAP and DBT Program Support, India, are acknowledged. Central Animal Facility at Indian Institute of Science is greatfully acknowledged for the supply of nude mice. Also, we thank the Indian National Science Academy, New Delhi, for the award of honarary scientist position to GSRSR.

\section{References}

Aggarwal BB, Shishodia S, Sandur SK, Pandey MK and Sethi G 2006 Inflammation and cancer how hot is the link? Biochem. Pharmacol. 72 1605-1621

Brookes PS, Morse K, Ray D, Tompkins A, Young SM, Hilchey S, Salim S, Konopleva M, Andreeff M, Phipps R and Bernstein SH 2007 The triterpenoid 2-cyano-3,12dioxooleana-1,9-dien-28-oic acid and its derivatives elicit human lymphoid cell apoptosis through a novel pathway involving the unregulated mitochondrial permeability transition pore. Cancer Res. 67 1793-1802

Ding A, Nathan CF, Graycar J, Derynck R, Stuehr DJ and Srimal S 1990 Macrophage deactivating factor and transforming growth factors-beta 1 -beta 2 and -beta 3 inhibit induction of macrophage nitrogen oxide synthesis by IFN-gamma. $J$. Immunol. 145 940-944

Gayathri B, Manjula N, Vinaykumar KS, Lakshmi BS and Balakrishnan A 2007 Pure compound from Boswellia serrata extract exhibits anti-inflammatory property in human PBMCs and mouse macrophages through inhibition of TNFalpha, IL-1beta, NO and MAP kinases. Int. Immunopharmacol. 7 473-482
Hail N Jr, Konopleva M, Sporn M, Lotan R and Andreeff M 2004 Evidence supporting a role for calcium in apoptosis induction by the synthetic triterpenoid 2-cyano-3,12-dioxooleana-1,9dien-28-oic acid CDDO. J. Biol. Chem. 279 11179-11187

Hansen JB, Petersen RK, Larsen BM, Bartkova J, Alsner J and Kristiansen K 1999 Activation of peroxisome proliferatoractivated receptor gamma bypasses the function of the retinoblastoma protein in adipocyte differentiation. J. Biol. Chem. 274 2386-2393

Honda T, Rounds BV, Gribble GW, Suh N, Wang Y and Sporn MB 1998 Design and synthesis of 2-cyano-3,12-dioxoolean1,9-dien-28-oic acid, a novel and highly active inhibitor of nitric oxide production in mouse macrophages. Bioorg. Med. Chem. Lett. 8 2711-2714

Honda T, Rounds BV, Bore L, Favaloro FG Jr, Gribble GW, Suh N, Wang Y and Sporn MB 1999 Novel synthetic oleanane triterpenoids a series of highly active inhibitors of nitric oxide production in mouse macrophages. Bioorg. Med. Chem. Lett. 9 3429-3434

Hyer ML, Shi R, Krajewska M, Meyer C, Lebedeva IV, Fisher PB and Reed JC 2008 Apoptotic activity and mechanism of 2-cyano3,12-dioxoolean-1,9-dien-28-oic-acid and related synthetic triterpenoids in prostate cancer. Cancer Res. 68 2927-2933

Ito Y, Pandey P, Place A, Sporn MB, Gribble GW, Honda T, Kharbanda S and Kufe D 2000 The novel triterpenoid 2-cyano3,12-dioxoolean-1,9-dien-28-oic acid induces apoptosis of human myeloid leukemia cells by a caspase-8-dependent mechanism. Cell Growth Differ. 11 261-267

Ito Y, Pandey P, Sporn MB, Datta R, Kharbanda S and Kufe D 2001 The novel triterpenoid CDDO induces apoptosis and differentiation of human osteosarcoma cells by a caspase8 dependent mechanism. Mol. Pharmacol. 59 1094-1099

Kim KB, Lotan R, Yue P, Sporn MB, Suh N, Gribble GW, Honda T, Wu GS, Hong WK and Sun SY 2002 Identification of a novel synthetic triterpenoid, methyl-2-cyano-3,12-dioxooleana1,9-dien-28-oate, that potently induces caspase-mediated apoptosis in human lung cancer cells. Mol. Cancer Ther. 1 177-184

Konopleva M, Tsao T, Ruvolo P, Stiouf I, Estrov Z, Leysath CE, Zhao S, Harris D, et al. 2002 Novel triterpenoid CDDO-Me is a potent inducer of apoptosis and differentiation in acute myelogenous leukemia. Blood 99 326-335

Konopleva M, Tsao T, Estrov Z, Lee RM, Wang RY, Jackson CE, McQueen T, Monaco G, et al. 2004 The synthetic triterpenoid 2-cyano-3,12-dioxooleana-1,9-dien-28-oic acid induces caspase-dependent and -independent apoptosis in acute myelogenous leukemia. Cancer Res. 64 7927-7935

Konopleva M, Zhang W, Shi YX, McQueen T, Tsao T, Abdelrahim M, Munsell MF, Johansen M, et al. 2006 Synthetic triterpenoid 2-cyano-3,12-dioxooleana-1,9-dien-28-oic acid induces growth arrest in HER2-overexpressing breast cancer cells. Mol. Cancer Ther. 5 317-328

Korsmeyer SJ 1992 Bcl-2 initiates a new category of oncogenes regulators of cell death. Blood $\mathbf{8 0} 879-886$

Lala PK and Orucevic A 1998 Role of nitric oxide in tumor progression lessons from experimental tumors. Cancer Metastasis Rev. 17 91-106

Lapillonne H, Konopleva M, Tsao T, Gold D, McQueen T, Sutherland RL, Madden T and Andreeff M 2003 Activation of peroxisome proliferator-activated receptor gamma by a novel 
synthetic triterpenoid 2-cyano-3,12-dioxooleana-1,9-dien-28oic acid induces growth arrest and apoptosis in breast cancer cells. Cancer Res. 63 5926-5939

Liby K, Honda T, Williams CR, Risingsong R, Royce DB, Suh N, Dinkova-Kostova AT, Stephenson KK, et al. 2007a Novel semisynthetic analogues of betulinic acid with diverse cytoprotective, antiproliferative, and proapoptotic activities. Mol. Cancer Ther. 6 2113-2119

Liby KT, Yore MM and Sporn MB 2007b Triterpenoids and rexinoids as multifunctional agents for the prevention and treatment of cancer. Nat. Rev. Cancer 7 357-369

Lu H, Ouyang W and Huang C 2006 Inflammation, a key event in cancer development. Mol. Cancer Res. 4 221-233

Palmer RM, Ashton DS and Moncada S 1988 Vascular endothelial cells synthesize nitric oxide from L-arginine. Nature (London) 333 664-666

Petronelli A, Saulle E, Pasquini L, Petrucci E, Mariani G, Biffoni M, Ferretti G, Scambia G, et al. 2009 High sensitivity of ovarian cancer cells to the synthetic triterpenoid CDDOImidazolide. Cancer Lett. 282 214-228

Place AE, Suh N, Williams CR, Risingsong R, Honda T, Honda Y, Gribble GW, Leesnitzer LM, et al. 2003 The novel synthetic triterpenoid, CDDO-imidazolide, inhibits inflammatory response and tumor growth in vivo. Clin. Cancer Res. 9 2798-2806

Radomski MW, Palmer RM and Moncada S 1990 An L-arginine/ nitric oxide pathway present in human platelets regulates aggregation. Proc. Nat. Acad. Sci. USA 87 5193-5197

Reed JC 1997 Double identity for proteins of the Bcl-2 family. Nature (London) 387 773-776

Samudio I, Konopleva M, Hail N Jr, Shi Y, McQueen T, Hsu T, Evans R, Honda T, et al. 2005 2-Cyano-3,12-dioxooleana-1,9dien-28-imidazolide CDDO-Im directly targets mitochondrial glutathione to induce apoptosis in pancreatic cancer. J. Biol. Chem. 280 36273-36282
Samudio I, Konopleva M, Pelicano H, Huang P, Frolova O, Bornmann W, Ying Y, Evans R, Contractor R and Andreeff M 2006 A novel mechanism of action of methyl-2-cyano-3,12 dioxoolean-1,9 diene-28-oate direct permeabilization of the inner mitochondrial membrane to inhibit electron transport and induce apoptosis. Mol. Pharmacol. 69 1182-1193

Subba Rao GS, Kondaiah P, Singh SK, Ravanan P and Sporn MB 2008 Chemical modifications of natural triterpenes - glycyrrhetinic and boswellic acids evaluation of their biological activity. Tetrahedron 64 11541-11548

Suh N, Wang Y, Honda T, Gribble GW, Dmitrovsky E, Hickey WF, Maue RA, Place AE, et al. 1999 A novel synthetic oleanane triterpenoid, 2-cyano-3,12-dioxoolean-1,9-dien-28-oic acid, with potent differentiating, antiproliferative, and antiinflammatory activity. Cancer Res. 59 336-341

Wajapeyee N and Somasundaram K 2003 Cell cycle arrest and apoptosis induction by activator protein 2alpha AP-2alpha and the role of p53 and p21WAF1/CIP1 in AP-2alpha-mediated growth inhibition. J. Biol. Chem. 278 52093-52101

Wang Y, Porter WW, Suh N, Honda T, Gribble GW, Leesnitzer LM, Plunket KD, Mangelsdorf DJ, et al. 2000 A synthetic triterpenoid, 2-cyano-3,12-dioxooleana-1,9-dien-28-oic acid $\mathrm{CDDO}$, is a ligand for the peroxisome proliferator-activated receptor gamma. Mol. Endocrinol. 14 1550-1556

Yang E and Korsmeyer SJ 1996 Molecular thanatopsis a discourse on the BCL2 family and cell death. Blood 88 386-401

Yawata A, Adachi M, Okuda H, Naishiro Y, Takamura T, Hareyama M, Takayama S, Reed JC and Imai K 1998 Prolonged cell survival enhances peritoneal dissemination of gastric cancer cells. Oncogene 16 2681-2686

Zou W, Yue P, Khuri FR and Sun SY 2008 Coupling of endoplasmic reticulum stress to CDDO-Me-induced upregulation of death receptor 5 via a CHOP-dependent mechanism involving JNK activation. Cancer Res. 68 7484-7492

MS received 15 December 2010; accepted 25 February 2011

ePublication: 16 May 2011

Corresponding editor: SEYEd E HaSNAIN 